U.S. Department of the Interior

U.S. Geological Survey

\title{
Paleozoic Fossils in Cades Cove, Great Smoky Mountains National Park, \\ Tennessee and North Carolina
}

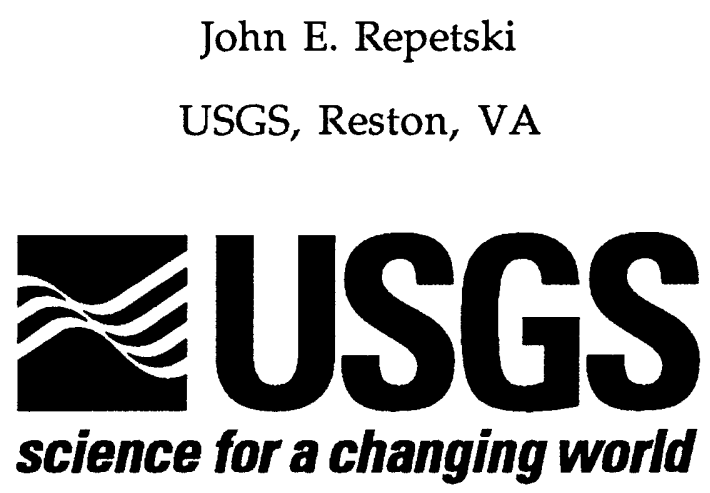

Open-File Report 97-747

This report is preliminary and has not been reviewed for conformity with U.S. Geological Survey editorial standards or with the North American Stratigraphic Code. Any use of trade, product, or firm names is for descriptive purposes only and does not imply endorsement by the U.S. Government 


\title{
Paleozoic Fossils in Cades Cove, Great Smoky Mountains National Park, \\ Tennessee and North Carolina
}

\author{
John E. Repetski \\ U.S. Geological Survey
}

Unlike the vast majority of the bedrock underlying the Great Smoky Mountains National Park, which is barren of fossils, the bedrock of much of Cades Cove (Figure 1) is carbonate sedimentary rock of marine origin. These lower Paleozoic carbonate rocks, assignable to the Jonesboro Limestone of the Knox Group (Upper Cambrian - Lower Ordovician), do contain the fossilized remains of several groups of marine animals. Although fossils are not uncommon in these rocks, they are mostly so small that they are easily overlooked, or they require a microscope for examination. For a variety of reasons, the limestones and dolostones of Cades Cove have received very little paleontological attention. This report is a preliminary summary of the fossils known or available from Cades Cove.

\section{MICROFOSSILS:}

Conodonts are tiny (generally 0.1 to $1 \mathrm{~mm}$ ), calcium phosphate, toothshaped microfossils that were the only hard parts of a group of extinct marine animals. These animals, also called conodonts, were common to abundant in most marine environments from the Late Cambrian through the Triassic Periods, that is from about 510 million to about 205 million years ago. Conodonts are known from five samples of the Jonesboro Limestone in Cades Cove, as follows: 


\section{Sample SOCC-25 [USGS fossil locality 10448-CO]:}

Collected by A.P. Schultz \& R.C. Orndorff; locality published in Orndorff and others (1988). This sample, as well as SOCC-26 and SOCC-27, were processed and the faunas initially analyzed by Orndorff and A.G. Harris in USGS internal report ( $E \& R$ ) O\&G-86-4; the faunas were re-analyzed for the present report.

Colaptoconus quadraplicatus (Branson \& Mehl) quadraplicatiform elements triplicatiform els.

29 Drepanoistodus concavus (Branson \& Mehl)

6 Eucharodus parallelus (Branson \& Mehl)

1 E. toomeyi (Ethington \& Clark)

5 aff. E. parallelus

9 cf. Laurentoscandodus triangularis (Furnish)

16 Macerodus dianae Fahraeus \& Nowlan Rossodus? n. sp. coniform elements

9 oistodontiform els.

1 "Scolopodus" acontiodiformis Repetski

5 "S." filosus Ethington \& Clark

$88 \quad$ Striatodontus? prolificus Ji \& Barnes

$1 \quad$ Ulrichodina abnormalis (Branson \& Mehl)

18 Genus \& species undetermined

1 unassigned oistodontiform element

11 indeterminate coniform elements 
Age: Early Ordovician; early middle Ibexian; Macerodus dianae Zone.

\section{Sample SOCC-26 [USGS foss. loc. no. 10449-CO]:}

Collected by A.P. Schultz \& R.C. Orndorff; locality published in Orndorff and others (1988).

1 Colaptoconus quadraplicatus (Branson \& Mehl)

$1 \quad$ Striatodontus? prolificus Ji \& Barnes

1 indeterminate fragment

Age: Early Ordovician; early middle Ibexian; "Low Diversity Interval" to Macerodus dianae Zone.

\section{Sample SOCC-27 [USGS foss. loc. no. 10450-CO]:}

Collected by A.P. Schultz \& R.C. Orndorff; locality published in Orndorff and others (1988).

1 Colaptoconus quadraplicatus (Branson \& Mehl); triplicatiform element

1 cf. Eucharodus parallelus (Branson \& Mehl)

5 indeterminate fragments

Age: Early Ordovician; middle or late Ibexian; "Low Diversity Interval" to Reutterodus andinus Zone.

\section{Sample RBN-1941-1 [ USGS fossil locality number :}

Collected by R.B. Neuman, in 1941. Sample represents matrix from sample collected for macrofossils; processed by Repetski.

Colaptoconus quadraplicatus (Branson \& Mehl) 
4 Drepanoistodus concavus (Branson \& Mehl); drepanodontiform els.

3 cf. Eucharodus toomeyi (Ethington \& Clark)

Rossodus? aff. R. manitouensis Repetski \& Ethington

1 coniform element

3 "Scolopodus" filosus Ethington \& Clark

$1 \quad$ Striatodontus? prolificus Ji \& Barnes

1 Ulrichodina deflexa Furnish

1 unassigned drepanodontiform element

2 unassigned scandodontiform els.

Age: Early Ordovician; early middle Ibexian; Macerodus dianae to lower part of Acodus deltatus-Oneotodus costatus Zone.

\section{Sample Cades Cove block 97-1:}

Collected by C.S. Southworth, 1997; sample was a block of silicified-

brachiopod-rich lime wackestone. Sample was processed by Repetski in acetic acid as a single block to recover the brachiopods as well as the acid-insoluble conodonts and possibly other microfossils. About one-third to one-half of the block was dissolved before neutralization of the acid bath, so that many of the brachiopods are partially exposed from the etched block. The conodonts include:

Colaptoconus quadraplicatus (Branson \& Mehl) quadraplicatiform elements

24 triplicatiform elements

2 Drepanodus sp. cf. D. arcuatus Pander; drepanodontiform element 
7 Drepanoistodus sp., aff. D. concavus (Branson \& Mehl)

11 Eucharodus parallelus (Branson \& Mehl)

2 Eucharodus sp.

2 Eucharodus? sp.

$2 \quad$ Paroistodus? n. sp.

$4 \quad$ Scalpellodus? sp.

Utahconus? n. sp.

9 coniform elements

4 scandodontiform els.

$5 \quad$ Ulrichodina deflexa Furnish

1 unassigned drepanodontiform element

1 Genus \& species indeterminate

14 indeterminate coniform elements

Age: Early Ordovician; early middle Ibexian; Macerodus dianae to lower part of Acodus deltatus-Oneotodus costatus Zone.

\section{MACROFOSSILS:}

Brachiopods are the most common of the known shelly macrofossils in the Cades Cove limestone bedrock, followed by rare mollusks (including gastropods and nautiloid cephalopods) and trilobites. Neuman (1947) collected the only known published macrofauna; the identifications were made by G.A. Cooper of the Smithsonian Institution.

Brachiopods:

Diaphelasma pennsylvanicum Ulrich \& Cooper; (locality 1 in Neuman, 1947) Finkelnburgia virginica Ulrich \& Cooper; (locality 1 in Neuman, 1947) 
Xenelasma syntrophioides Ulrich \& Cooper; (locality 3 and several other exposures in presumably one bed spottily exposed over about a mile, in Neuman, 1947)

\section{Gastropods:}

cf. Orthoceras (nautiloid cephalopod); (locality 2 in Neuman, 1947)

Hormotoma sp.; (locality 1 in Neuman, 1947)

Lecanospira sp.; ((locality 2 and at several other sites, presumably in several stratigraphic horizons, according to Neuman, 1947)

\section{Trilobites:}

Hystricurus(?) sp.; (locality 1 in Neuman, 1947)

The three species of brachiopod reported by Neuman (1947) are represented by approximately ten valves of each species. These are loose silicified specimens and are reposited in the collections of the Paleobiology Department of the U.S. National Museum of Natural History, Washington, D.C. They are small and extremely delicate. There is no record of any of the cephalopods or gastropods being reposited in the collections. According to Neuman's recollections (oral commun., 1997), some of the identifications of the mollusks were field identifications, with the specimens not collected. This is the case with the trilobite as well; apparently this record is based on one specimen exposed on a pinnacle of limestone, which was not collected.

Additional brachiopods were recovered from the block (97-1) collected by Southworth (mentioned above in conodont section). Several dozen specimens were released in the acidizing process. These also are small and fragile; preservational quality varies widely. These specimens most likely 
represent the same species identified by Cooper for Neuman. More could be extracted rather routinely from the appropriately silicified horizon(s).

\section{BIOSTRATIGRAPHY AND CORRELATION:}

The macro- and microfossils are consistent in indicating a lower middle Ibexian (Lower Ordovician) stratigraphic assignment for their host rocks. The fossils and rocks are totally consistent with their deposition on the carbonate continental shelf or ramp in tropical or semi-tropical latitudes on the Iapetan (proto-Atlantic) Ocean edge of the Laurentian (including present North America) paleocontinent (Figure 2). The best correlation with Knox Group rocks in eastern Tennessee is with the uppermost part of the Chepultepec Dolomite, the Kingsport Formation, to the lower, probably lowermost, part of the Mascot Dolomite in sections west of the Saltville fault (e.g., see Repetski, 1985). This interval is approximately equivalent to that of the Longview-Kingsport interval of the Knox Group of older literature. To the northeast of the Great Smoky Mountains National Park, and in the eastern thrust belts of East Tennessee, the equivalent interval would be at some level in the Jonesboro Limestone. Systematically collected fossils from the Jonesboro are needed for precise correlation. Figure 3 shows the total possible stratigraphic ranges in the Ordovician of all of the fossil collections treated in this report. 
References Cited --

Orndorff, R.C., Harris, A.G., and Schultz, A.P., 1988, Reevaluation of conodont color alteration patterns in Ordovician rocks, east-central Valley and Ridge and western Blue Ridge provinces, Tennessee: U.S. Geological Survey Bulletin 1839, p. D1-D10.

Neuman, R.B., 1947, Notes on the geology of Cades Cove, Great Smoky Mountains National Park, Tennessee: Journal of the Tennessee Academy of Science, v. 22, no. 3, p. 167-172.

Repetski J.E., 1985, Conodont biostratigraphy of the Knox Group at the Thorn Hill and River Ridge sections, northeastern Tennessee, In Walker, K.R. (ed.), The geologic history of the Thorn Hill Paleozoic section (Cambrian-Mississippian), eastern Tennessee: University of Tennessee, Department of Geological Sciences, Studies in Geology 10, p. 25-31.

Witzke, B.J., 1990, Palaeoclimatic constraints for Palaeozoic palaeolatitudes of Laurentia and Euramerica, In McKerrow, W.S., and Scotese, C.R., (eds.), Palaeozoic palaeogeography and biogeography: London, Geological Society Memoir No. 12, p. 57-73. 


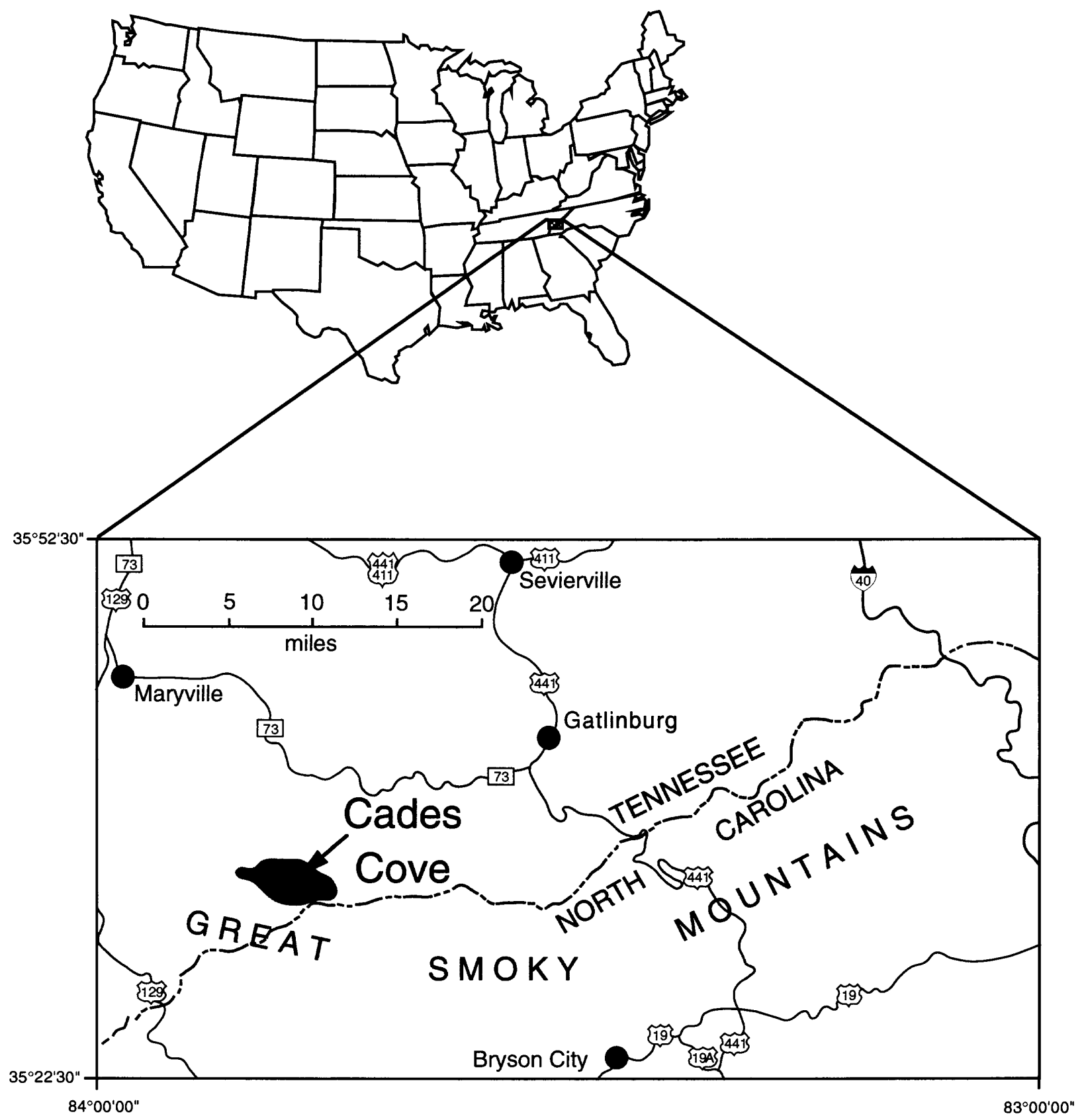

Figure 1. Map showing the location of Cades Cove in the Great Smoky Mountains. 


\section{EARLY ORDOVICIAN TIME}

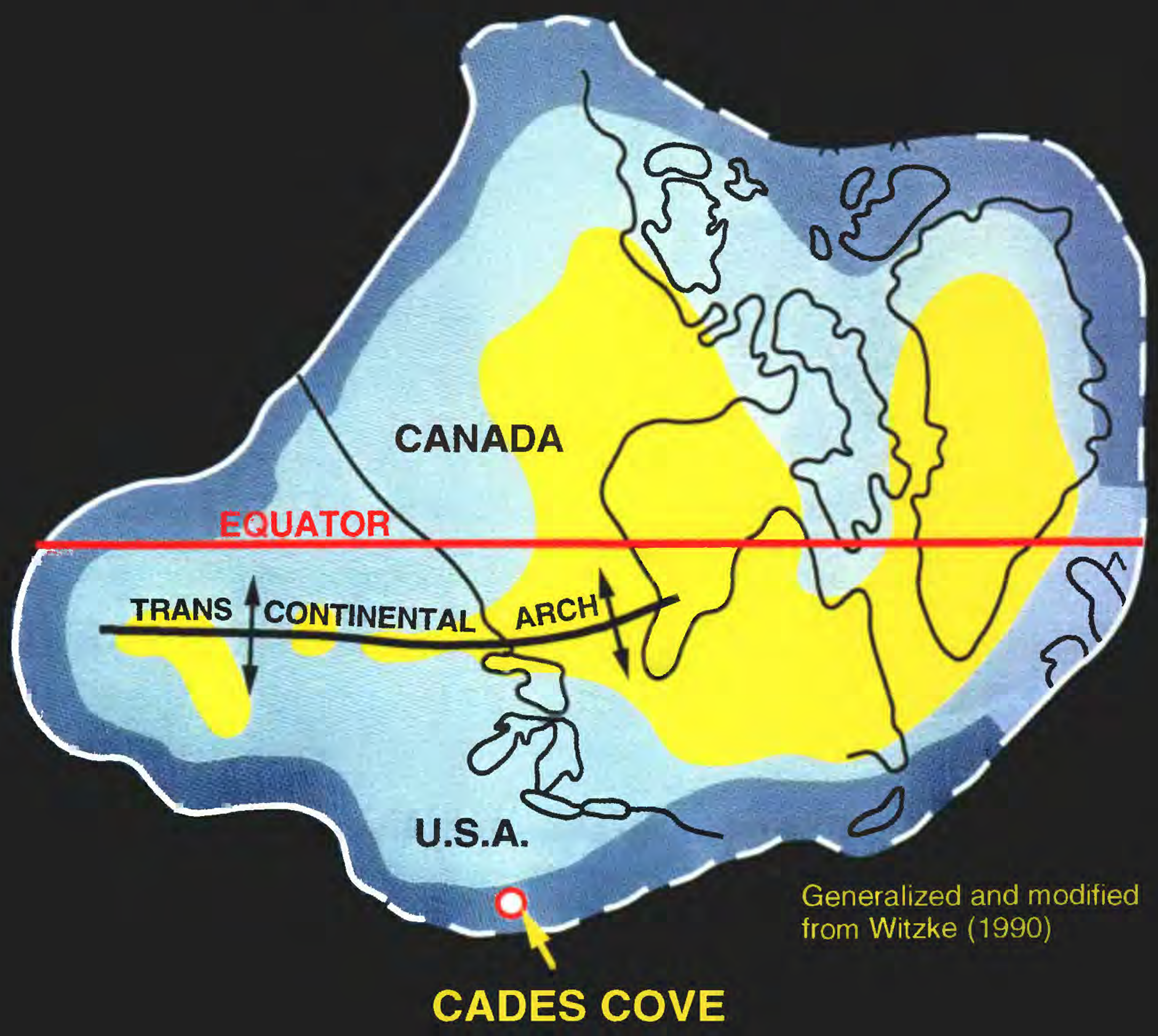

LAND AREA

SHALLOW-WATER CHIEFLY CARBONATE DEPOSITION

CARBONATE SHELF, LIMESTONE DEPOSITION

Figure 2. Paleogeographic reconstruction of North America for Early Ordovician time, showing relative location of Cades Cove limestone. 


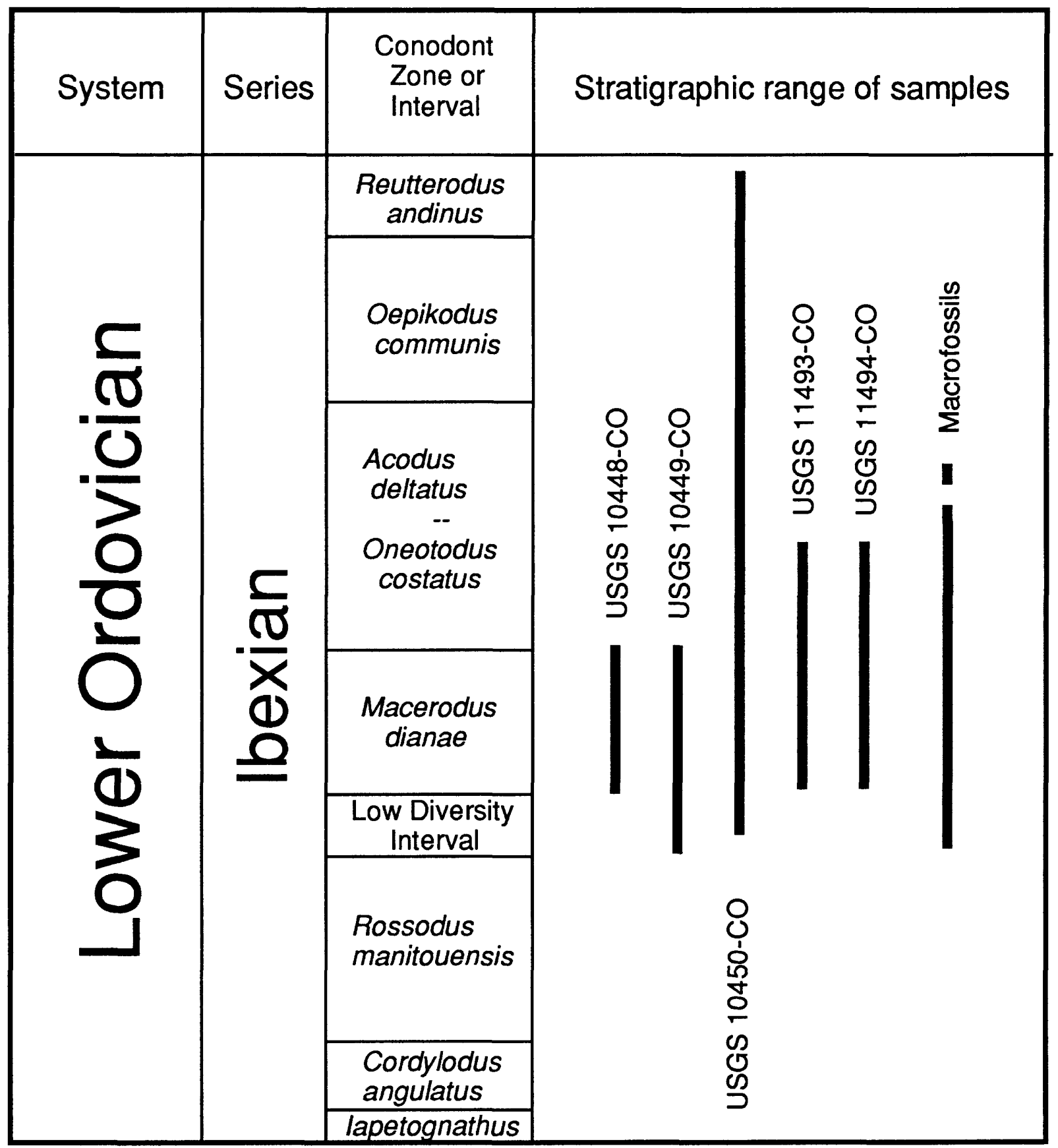

Figure 3. Diagram showing possible stratigraphic range in the Lower Ordovician of fossils known from Cades Cove. 